\title{
Social and Eco-Friendly Entrepreneurship: The Keys to Sustainability
}

http://doi.org/10.21272/bel.5(1).118-126.2021

Liudmyla V. Starchenko, ORCID: https://orcid.org/0000-0001-8606-7246

$\mathrm{PhD}$, Associate Professor, The Department of Marketing, Sumy State University, Sumy, Ukraine

Yaryna V. Samusevych, ORCID: https://orcid.org/0000-0001-7048-8388

$\mathrm{PhD}$, Senior lecturer, The Department of Accounting and Taxation, Sumy State University, Sumy, Ukraine

Kateryna Demchuk, ORCID: https://orcid.org/0000-0001-9556-1625

Student, University of Applied Sciences of Hamburg, Hamburg, Germany

\begin{abstract}
The article summarizes the arguments and counterarguments in the scientific discussion on the development of sustainable entrepreneurship. The main purpose of the study is to identify the essential characteristics and key determinants of success of sustainable entrepreneurship initiatives. Systematization of literature sources showed that the current stage of entrepreneurship is characterized by the transition from the concept of maximizing profitability to the formation of long-term sustainability. Existing theoretical and empirical research shows that sustainable entrepreneurship is an activity aimed at balancing economic, social and environmental challenges. The theoretical analysis of the results of basic research on sustainable entrepreneurship has identified a list of key internal and external determinants that contribute to the development of sustainable entrepreneurship. It is determined that the key internal characteristics of the entrepreneur are the level of his motivation and qualification. At the same time, among external factors, the education system, the availability of state environmental and social policy measures, as well as public perception and support of social and environmental initiatives play a significant role in promoting sustainable entrepreneurship. It is established that the existing empirical research revealed the differentiation of results for companies of different sizes and at different stages of operation, as well as depending on the form of ownership and sector of activity. The results of the analysis provide a scientific basis for further research on the key determinants of the effectiveness of sustainable entrepreneurship initiatives, the identification of the most promising sectors for social and environmental initiatives, and the study of links with social, environmental and economic parameters.
\end{abstract}

Keywords: Enterprise, Sustainability, Sustainable Entrepreneurship, Social Enterprise, Environmentally-Oriented Enterprise, Determinants.

JEL Classification: L26, L31, Q01, Q56.

Cite as: Starchenko, L.V., Samusevych, Ya., Demchuk, K. (2020). Social and Eco-Friendly Enterpreneurship: The Keys to Sustainability. Business Ethics and Leadership, 5(1), 118-126. http://doi.org/10.21272/bel.5(1).118-126.2021.

Received: 10 January 2021

Accepted: 01 March 2021

Published: 30 March 2021

Copyright: (C) 2021 by the author. Licensee Sumy State University, Ukraine. This article is an open access article distributed under the terms and conditions of the Creative Commons Attribution (CC BY) license (https://creativecommons.org/licenses/by/4.0/).

\section{Introduction}

Traditionally, the development of entrepreneurship is associated with the achievement of economic goals. At the same time, there are often negative social effects (increasing inequality in income distribution) or environmental consequences (depletion of natural resources, increasing environmental pollution). The solution of these problems becomes especially relevant in the context of increased attention to sustainable development, which requires balancing economic, environmental and social manifestations of any social activity. It is important that at the present stage the positive connection between the development of traditional forms of entrepreneurship and economic and social parameters defined by Sustainable Development Goals is empirically confirmed, while the connection with environmental parameters remains inverse (Dhahri \& Omri, 2018). At the same time, it is proved that the organization of a business-friendly regulatory environment contributes to the growth of the financial performance of companies and their human potential (Kaya, 2020), which indicates 
significant prospects for the concept of sustainable entrepreneurship in terms of increasing business regulation loyalty. All this leads to the emergence of new forms of entrepreneurship, focused not only on making a profit but also on achieving certain goals that are important for external stakeholders of the enterprise. Such forms were social enterprises and environmentally friendly enterprises. The spread of these types of business has shown the relevance of the development of sustainable entrepreneurship and the search for factors that determine the success of achieving the goals of sustainable business growth.

\section{Literature Review}

The key features of the entrepreneur are traditionally considered through the use of opportunities and risktaking to achieve a certain goal. At the same time, the social entrepreneur is guided by a certain mission and aims to create social value for other entities through self-sufficient, financially successful and sustainable activities (Abu-Saifan, 2012). On the other hand, the need to develop corporate social responsibility and create social enterprises is evidenced by the study of customer feedback (Tsalikis and Seaton, 2020), because at the current stage of growing competition between companies it is necessary to increase the value of the enterprise for all its stakeholders. Moreover, leveling the concept of corporate social responsibility can lead to loss of consumer loyalty to the company and loss of value of its brand, as confirmed by empirical research (Husnain et al., 2020). One of the key factors ensuring the success of social entrepreneurship must be blended value orientation (Shin $\&$ Park, 2019). The growth of social capital and the development of social values and norms are factors that determine the development of another form of entrepreneurship - environmentally oriented, so-called "ecopreneurship" (Saleem et al., 2018). Besides, it is worth noting that the development of eco-friendly enterprises has a significant impact on the formation of environmentally conscious consumer behavior, in particular through "green" advertising (Hussain et al., 2020), which indicates not only the significant potential of the concept of sustainable business for its performance but also about its key role in the formation of a qualitatively new stage of development of the national economy. Greco \& de Jong (2017) highlight that the goal of sustainable entrepreneurship is to create a positive impact on society and the environment, which is even more important than the production of goods and services, so, creating value for society is crucial for sustainable entrepreneurship.

Lüdeke-Freund (2020) also emphasizes that the value of sustainable entrepreneurship is the formation of value for a wide range of stakeholders. The basis of the transformation of the business model of sustainable entrepreneurship is sustainable innovation, the introduction of which allows solving economic problems of the enterprise simultaneously with the achievement of environmental or social effect. Urbaniec (2018) offers a similar approach to defining the essence of sustainable entrepreneurship, considering it a set of business practices that create opportunities for innovative corporate activities in conjunction with environmental and social challenges. Innovation is also identified as a key driver of the formation of environmentally friendly entrepreneurship, also known as ecopreneurship (Rodríguez-García et al., 2019). On the other hand, there are also external effects of business innovation on the growth of the country's human potential (Sajjad et al., 2020), which indicates the systemic effects of an innovative approach to the development of sustainable entrepreneurship. Moreover, it is confirmed that financial innovations are not only the driver of small and medium business development but also have a huge potential for global economic growth (Umadia and Kasztelnik, 2020).

Tarnanidis \& Papathanasiou (2015) view sustainable entrepreneurship as a combination of three elements economic, environmental and social entrepreneurship. The authors' correlation analysis of external and internal attributes in terms of these three types of entrepreneurship shows that the highest level of interaction with other attributes show such parameters as improve life, defend social needs, energy savings, planning investments, sell goods for profit. Accordingly, these components can form the core of sustainable entrepreneurship. The existence of positive multilateral links between responsible management, financial sustainability, organizational performance has been empirically confirmed (El Amri et al., 2020), which proves the need for a comprehensive consideration of managerial, social, financial and environmental parameters in building a modern enterprise. On the other hand, it is determined that insufficient development of intellectual capital and lack of state support reduce the introduction of innovations by enterprises and the development of the innovation ecosystem (Ubreziova et al., 2020). That is why the most effective way to develop enterprises should be to balance their economic, environmental and human potential. Konys (2019) explores the key categories of the concept of sustainable entrepreneurship through bibliometric analysis, which determined that the main drivers in the development of the theoretical basis of sustainable entrepreneurship should be considered sustainability, entrepreneurship, sustainable development, social entrepreneurship, corporate sustainability, environmental entrepreneurship, corporate social responsibility, innovations, small and medium enterprises. The study of sustainable entrepreneurship in the context of achieving the goals of sustainable development has shown that countries focused on investing in achieving environmental and economic goals can provide prospects for strategic growth of sustainable entrepreneurship (Moya-Clemente et al., 2020). 
Fichter and Tiemann (2020) conduct an empirical study of the structural relationships between drivers and the prerequisites for the development of sustainable entrepreneurship, the results of which showed that a competitive business plan is a key to achieving sustainable development goals in startups. Besides, the general context of the establishment of the enterprise is important, such as the social goals of the founders, the focus on sustainable development, green economy, etc. The analysis shows that, despite the presence of certain different accents, the scientific literature has formed a general vision of the essence of sustainable entrepreneurship as a set of entrepreneurial activities aimed at achieving economic goals and fulfilling the social and/or environmental mission of the enterprise. At the same time, studies of the factors that determine the success of sustainable entrepreneurship are characterized by significant differentiation of the analyzed aspects. This testifies to the need for comprehensive generalizations and the formation of a general vision of the conceptual basis for effective organization of sustainable entrepreneurship.

\section{Methodology and Results}

The theoretical study of the conceptual foundations of sustainable entrepreneurship is realized using a set of structural and logical methods of analysis. In the first stage, it is advisable to conduct a study of the interest of Internet users and publishing activity on issues related to sustainable business. To do this, a trend analysis of queries on the Google network and a study of the frequency of Google Books concepts "sustainable entrepreneurship", "social entrepreneurship" and "environmental entrepreneurship" were conducted (Figure 1).

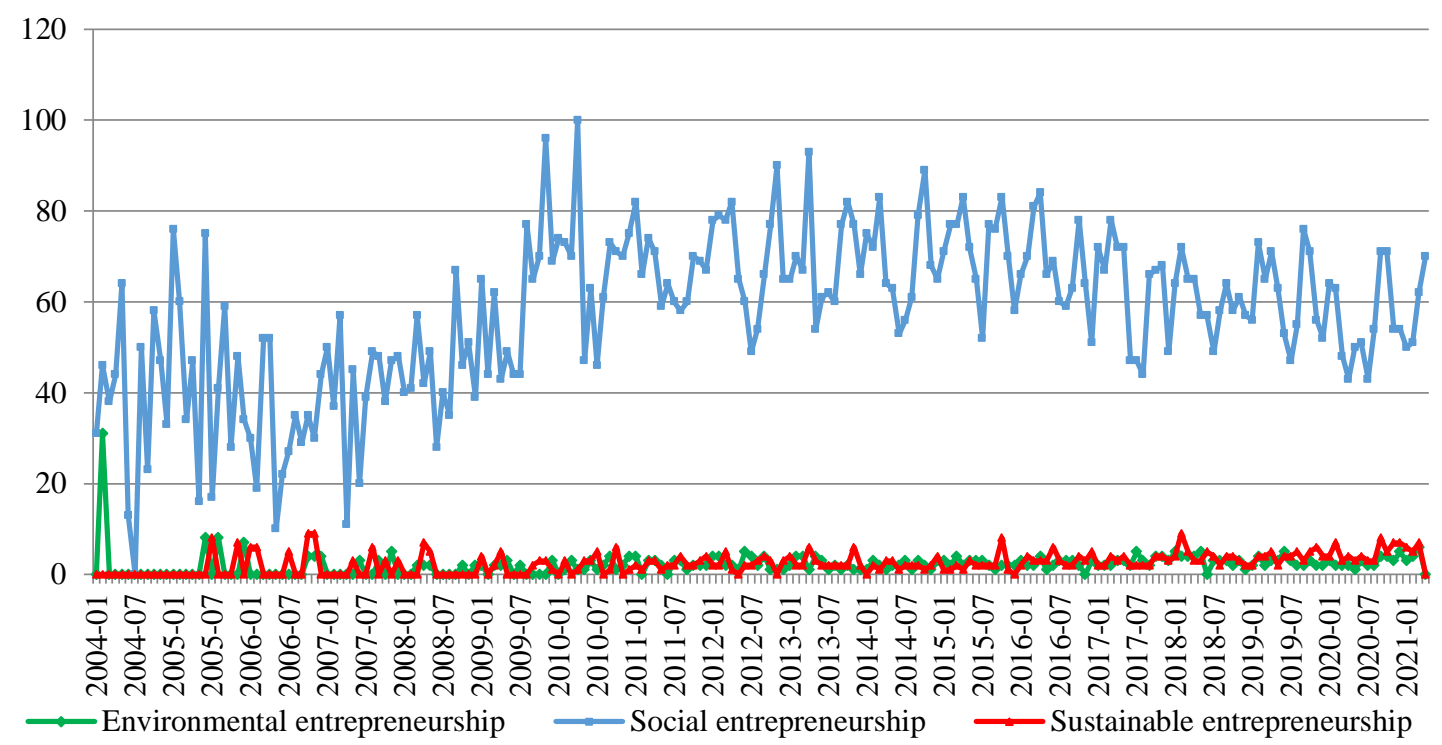

Figure 1.a. Results of Google Trends Analysis on the Users' Requests on "Sustainable Entrepreneurship", "Social Entrepreneurship", "Environmental Entrepreneurship" for 2004-2021

Source: Google Trends, 2021

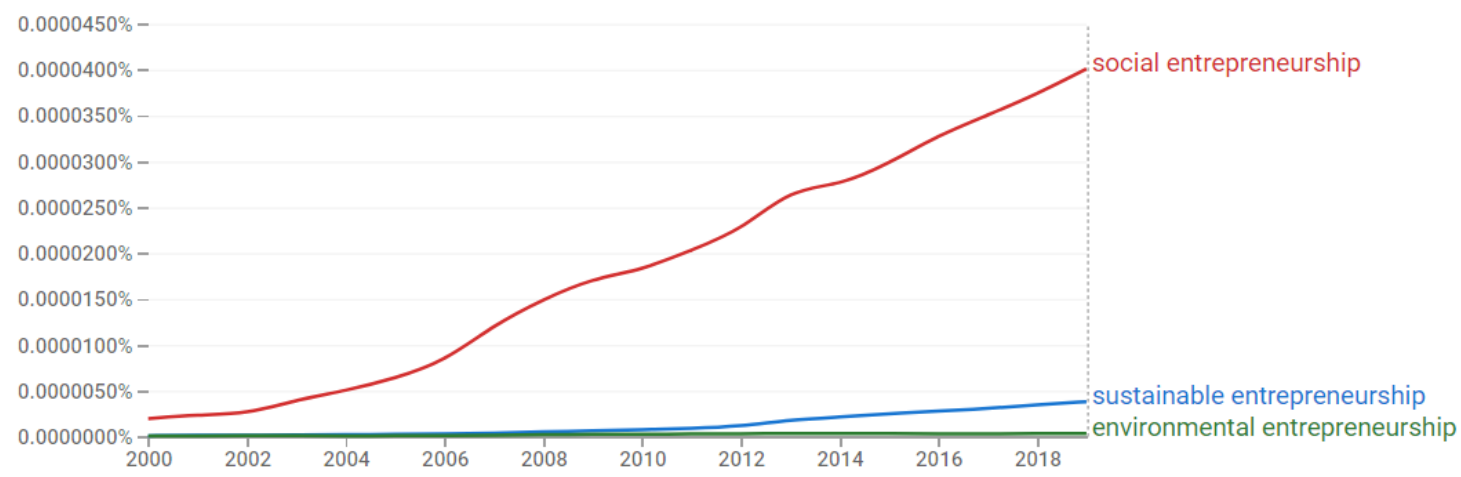

Figure 1.b. Results of Google Ngram Viewer Analysis on the Request "Sustainable Entrepreneurship", "Social Entrepreneurship", "Environmental Entrepreneurship" for 2000-2019

Figure 1. Results of the Analysis of the Interest in the Categories "Sustainable Entrepreneurship", "Social Entrepreneurship", "Environmental Entrepreneurship"

Source: Google Books Ngram Viewer, 2021 
The study points to the fact that the scientific interest and interest of Internet users most widely relate to the category of "social entrepreneurship". This can be traced throughout the study period, besides, the growth in the number of search queries (Fig. 1a) and mentions in publications (Fig. 1b) is constant and most dynamic since 2010. At the same time, the formation of Internet users' interest in the problem of sustainable entrepreneurship can be seen since 2005, and a significant increase in publishing activity - only since 2012 . Importantly, environmental entrepreneurship issues attract the attention of Internet users almost as often as the issue of sustainable entrepreneurship, while the number of references to environmental entrepreneurship in Google Books is significantly less than in other categories studied. This points to the fact that the environmental aspects of the study of sustainable entrepreneurship today remain the least studied. Comparisons and generalizations allowed identifying a list of factors that should be considered as determinants of the success of a sustainable enterprise. These key characteristics are shown in Table 1.

Table 1. The Results of Analysis of the Key Factors Determining Sustainable Entrepreneurship

\begin{tabular}{|c|c|c|c|c|c|c|c|c|c|c|c|c|c|c|c|c|c|}
\hline &  & 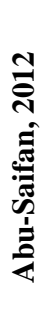 & 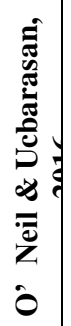 & 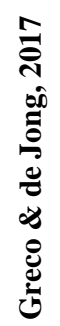 & 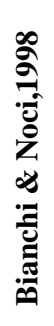 & 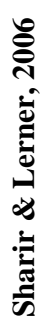 & 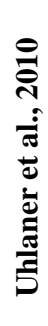 &  & 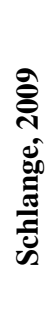 & 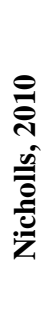 & 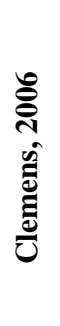 & 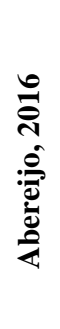 & 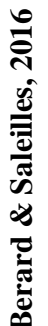 & 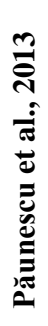 & 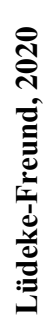 & 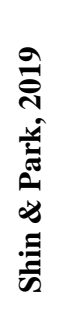 & 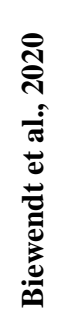 \\
\hline External-values orientation & & + & & & & & & + & & & & & & & & + & \\
\hline Internal motivation & & & & + & & & & & & & & & & & & & \\
\hline Stakeholder network & & & & & & + & & & + & & & & & & + & & \\
\hline Long-term planning & & & & + & & & & + & & & & & & & & & \\
\hline Education system & & & & & & & & & & & & + & + & + & & & \\
\hline State support & & & & & & & & & & & + & + & & & & & \\
\hline Green control & & & & & & & & & & & & & & & & & + \\
\hline Mixed team work & & & & & & + & & & & & & & + & & & & \\
\hline Company's size & & & & & + & & + & & & & & & & & & & \\
\hline Company's age & & & & & & & & + & & & & & & & & & \\
\hline Family ownership & & & & & & & + & & & & & & & & & & \\
\hline Belonging to tangible sectors & & & & & & & + & & & & & & & & & & \\
\hline Innovations & + & & & & & & & & & & & & & & + & & \\
\hline $\begin{array}{l}\text { Marketing \& technologies } \\
\text { potential }\end{array}$ & & & & & & & & + & & & & & & & & & \\
\hline Firm image & & & & & + & & & & & & & & & & & & \\
\hline Public acceptance & & & + & & + & & & & & + & & & & & & & \\
\hline
\end{tabular}

Source: Authors' generalization

A study of the history of sustainable small business development, conducted by Berard and Saleilles (2016), identified a list of factors that can ensure the success of the concept of sustainable entrepreneurship. These include the differentiation of skills and abilities of staff with a focus on lifelong learning, a combination of growth strategies, a significant level of normative identity, etc. Quite interesting are the results of an empirical study of the relationship between the parameters of the strategic vision of companies and their focus on sustainability (Jahanshahi et al., 2017). For example, sustainability-oriented businesses have been shown to have close direct links to value-oriented external stakeholders, long-term business planning, and expectations of fairness in meeting people's needs and desires. At the same time, the influence of control variables was important, which indicates the fact that the determinants of entrepreneurship sustainability are the young age of entrepreneurs, the significant potential of their marketing and technological skills, as well as the stability of the company and early stages of its development.

Unlike previous researchers, Abereijo (2016) focuses on external drivers to ensure the development of sustainable entrepreneurship. Thus, the central place is occupied by the education system, which allows future entrepreneurs to form a strategic vision of the balance between economic, social and environmental values and the potential for realization of this balance through entrepreneurial activity. Besides, the availability of state support plays a significant role through tax benefits, "green" loans, investments, etc. The role of the institute of education in promoting social entrepreneurship and social transformation is also emphasized by Păunescu et al. (2013). Biewendt et al. (2020) analyze external drivers of corporate sustainability in the context of limitations consequences of entrepreneurial activity on the environment. Given the fact that market 
mechanisms do not lead to the reduction in the use of natural resources, it is necessary to create incentives for the transition to new technologies and the production of products with reduced use of natural resources. Thus, the availability of resource control systems in countries is a factor that contributes to the sustainability of the business sector. It is also important to analyze trends in the formation of exploratory interest in the main phenomena associated with the issues of sustainable entrepreneurship. Thus, based on a previous study, we determine that most often the key factors in the context of sustainable entrepreneurship are "external values", "stakeholder network" and "public acceptance". The analysis results of the search queries frequency of Internet users in these categories in comparison with the interest in the concept of sustainable entrepreneurship are shown in Fig. 2.

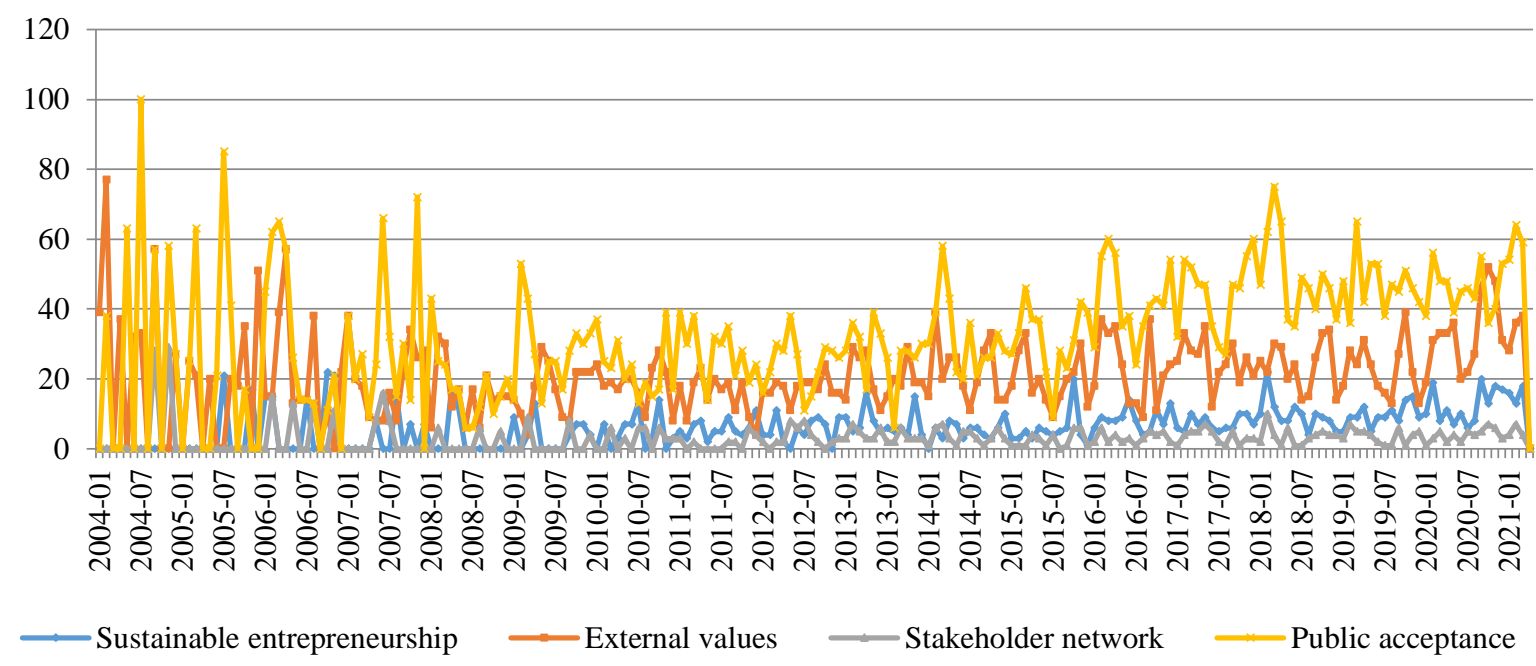

Figure 2. Results of Google Trends Analysis on the Internet Users' Requests on "Sustainable Entrepreneurship", "External Values", "Stakeholder Network", "Public Acceptance" for 2004-2021

Source: Google Trends, 2021

The results show that for Internet users, the priority category should be considered "public acceptance". The number of requests for this concept is the highest and almost does not change over time. It should also be noted a considerable interest in the concept of "external values". At the same time, the issue of "stakeholder network" attracts the interest of Internet users much less often. Thus, it can be stated that at the present stage of social development there is a transformation of understanding of the essence of entrepreneurship exclusively in terms of commercial interests of stakeholders to consider the public position and search for entrepreneurial value formed by non-financial factors. This point to the fact that the most important drivers of the success of sustainable entrepreneurship should be the formation of public trust and recognition of the company's mission by the society.

At the same time, indicators of the development of sustainable entrepreneurship are not only indicators of the growing interest of researchers and society, but also the real parameters of business operation. When studying the indicators of entrepreneurial activity, one should pay attention to those manifestations that reflect the increase in the level of business sustainability. Thus, the most comprehensive development of environmental entrepreneurship is presented by the specifics of the products (Fig. 3.a.). Thus, we can note that over the past 5 years in the European Union there has been almost a twofold increase in the number of products certified as organic. At the same time, the analysis by country shows that the leaders are Italy, France and Spain. However, most countries have demonstrated growth in ecolabel products. On the other hand, the issue of waste management remains relevant. To solve it, the policy of European countries involves the application of a new progressive approach to the concept of extended corporate responsibility (Fig. 3.b.), which is becoming increasingly common in recent years. 




Figure 3.a. Number of Ecolabel Products by Countries 2015,2019

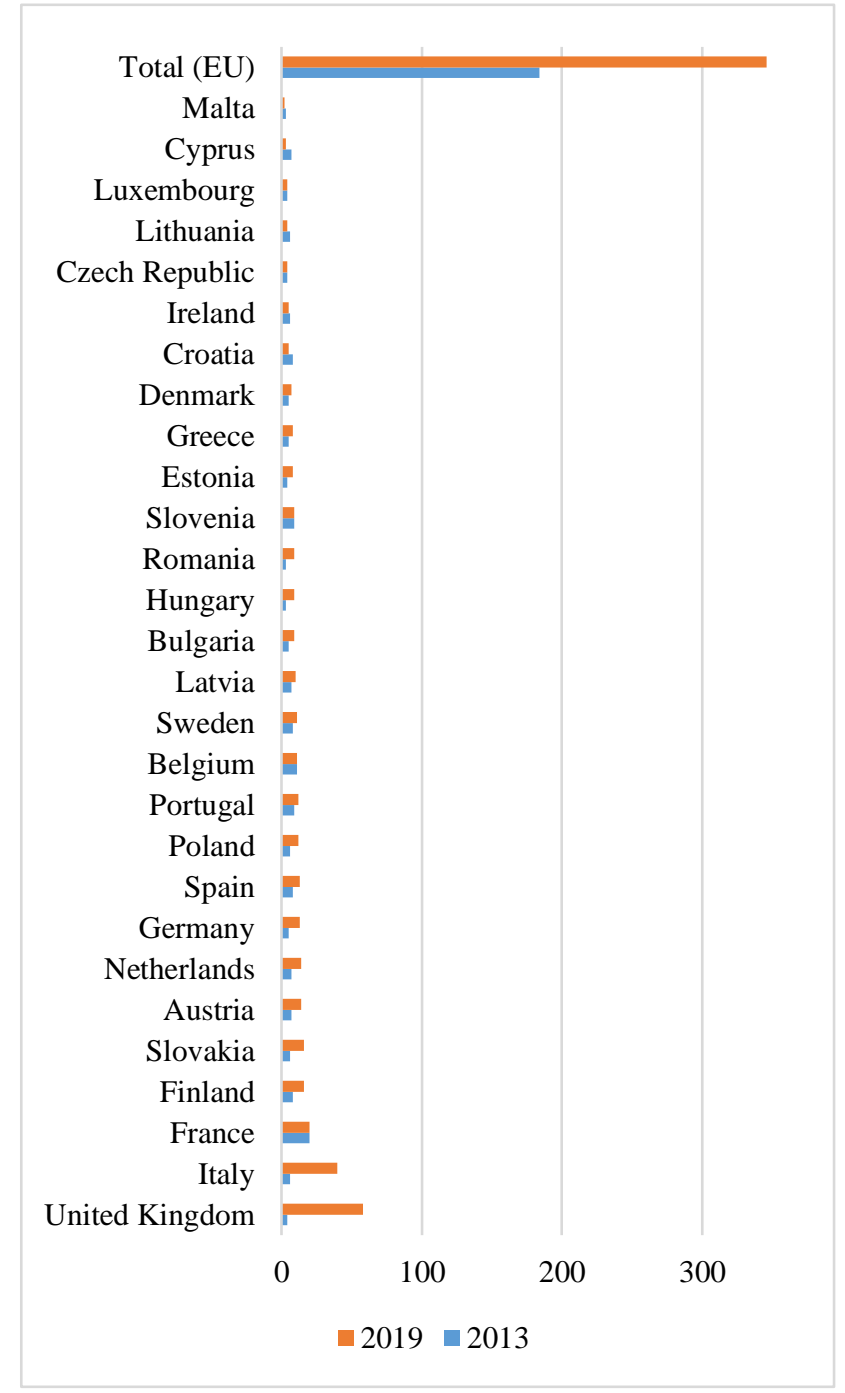

Figure 3.b. Number of Extended Producer Responsibility by Countries 2013

Figure 3. Indicators of Environmental Entrepreneurship Development in European Union

Source: European Commission, 2021

At the same time, the most important internal drivers of social entrepreneurship development are the parameters of human capital management of the company. A survey of 11,070 companies around the world, conducted by the international organization Deloitte, showed that at the present stage of development there is a high level of awareness of the importance of social capital in the enterprise (Fig. 4). At the same time, a much smaller share of companies is ready to implement changes in their activities to increase the level of implementation of certain areas of social capital development. 


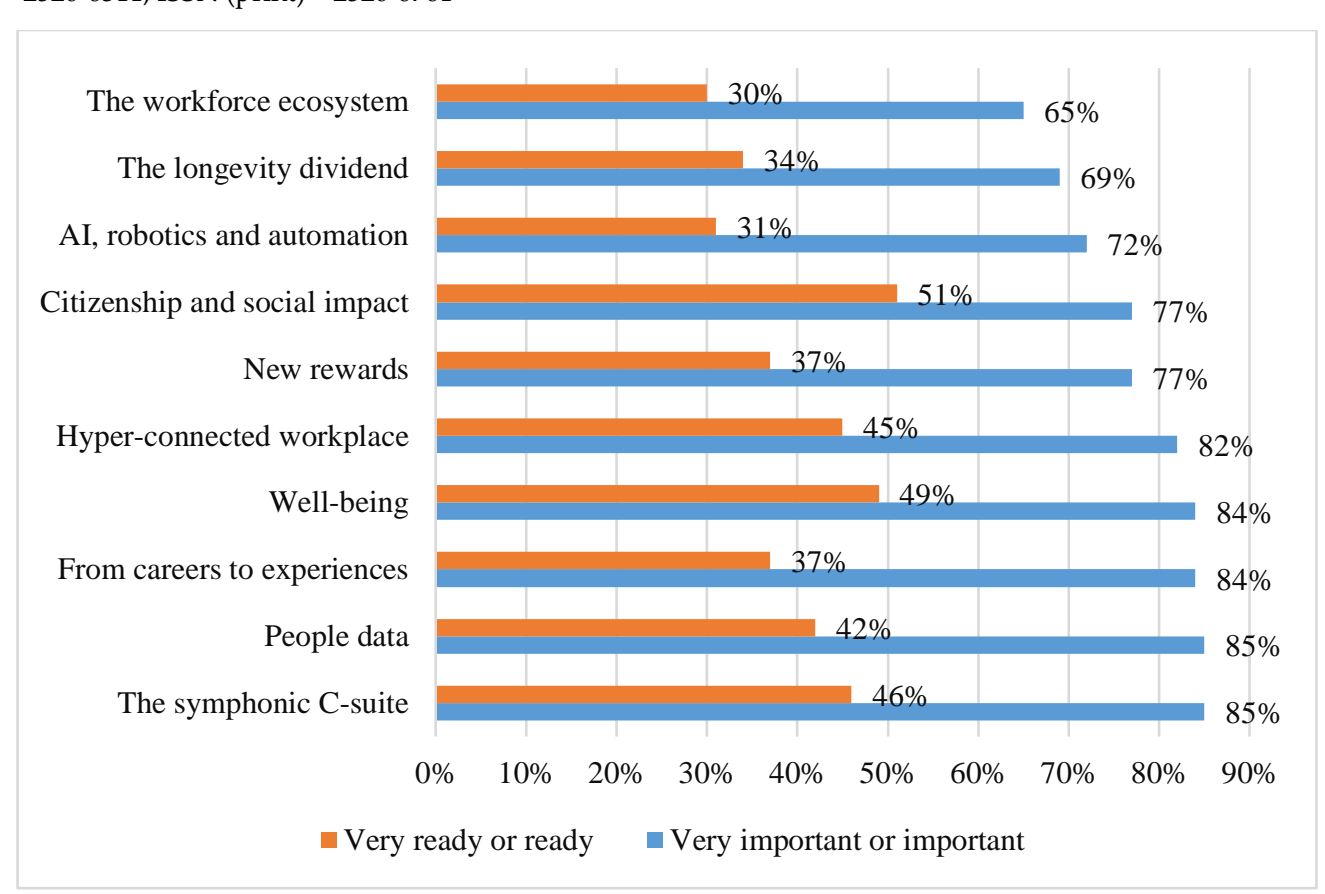

Figure 4. Trends of Companies' Human Capital Development in the World

Source: Deloitte, 2018

Analyzing some areas of development, we note that respondents consider the most important directions "The symphonic C-suite" that means strengthening the role of teamwork, which determines the company's activities and works as a single coherent mechanism, as well as "People data", which determines the importance of information to minimize personnel management risks. On the other hand, it is also important indicators that reflect the personal development of employees, which can be obtained in the process of working with the company, as well as relationships with the company ("From careers to experiences", "Well-being", "Hyperconnected workplace"). At the same time, it is more interesting to analyze the readiness of companies to implement changes on the way to the transition to social entrepreneurship. Thus, about half of the surveyed companies are ready to shape the company's strategy taking into account such areas as "Citizenship and social impact" and "Well-being". On the other hand, only a third of companies expressed readiness to develop in such areas as "The workforce ecosystem" and "AI, robotics and automation".

\section{Conclusions, Discussion and Recommendations}

The study indicates that the current stage of business development is characterized by the transition from the concept of maximizing profitability to the formation of long-term sustainability. Existing theoretical and empirical research shows that sustainable entrepreneurship is an activity aimed at balancing economic, social and environmental challenges. It is characterized by a combination of classic features of entrepreneurial activity, aimed at maximizing the key performance indicators, with the implementation of the external mission of the enterprise, related to the creation of value for external stakeholders. It is determined that the success of sustainable entrepreneurship initiatives is determined by both the internal motivational and qualification characteristics of the entrepreneur, and a number of external factors. In particular, the education system, the availability of state environmental and social policy measures, as well as public perception and support of social and environmental initiatives demonstrate a significant role in promoting sustainable entrepreneurship. At the same time, existing empirical studies show differentiation of results for companies of different sizes and at different stages of operation, as well as depending on the form of ownership and sector of activity. All this points to a wide field of further research on the key determinants of the effectiveness of sustainable entrepreneurship initiatives, the identification of the most promising sectors for social and environmental initiatives, and the study of the links with social, environmental and economic parameters.

\section{Acknowledgment}

The paper was supported by the Ministry of Education and Science of Ukraine and performed the results of the project "Structural-functional multiplex model of ecological tax system building in Ukraine in the context of national security" (registration number 0119U100759). 
Author Contributions. Conceptualization, Starchenko L., Samusevych Ya.; data curation, Starchenko L.; formal analysis, Samusevych Ya.; investigation, Starchenko L., Samusevych Ya., Demchuk K.; methodology, Starchenko L., Samusevych Ya.; project administration, Starchenko L.; supervision, Starchenko L., Samusevych Ya.; validation, Starchenko L., Samusevych Ya.; visualization, Demchuk K.; writing - original draft, Starchenko L., Samusevych Ya., Demchuk K.; writing - review \& editing, Starchenko L., Samusevych Ya., Demchuk K.

Funding. There is no funding for this research.

\section{References}

1. Abereijo, I.O. (2016). Ensuring Environmental Sustainability through Sustainable Entrepreneurship. In book: Economic Modeling, Analysis, and Policy for Sustainability. Publisher: IGI GlobalEditors, pp.234-249. https://doi.org/10.4018/978-1-5225-0094-0.ch012.

2. Abu-Saifan, S. (2012). Social Entrepreneurship: Definition and Boundaries. Technology Innovation Management Review. Available at: https://timreview.ca/sites/default/files/article PDF/Saifan TIMReview February2012 2.pdf.

3. Berard, C., and Saleilles, S. (2016). Sustainability-driven entrepreneurship and high-growth SMEs: How to combine Davids' and Goliaths' worlds? International Journal of Organisational Design and Engineering, 4(3/4), 195-212. Available at: https://halshs.archives-ouvertes.fr/halshs-01459141/document.

4. Bianchi, R., and Noci, G. (1998). "Greening” SMEs' Competitiveness. Small Business Economics, 11(3), 269-281. Available at: https://www.jstor.org/stable/40228980.

5. Biewendt, M., Blaschke, F., Böhnert, A. (2020). An Evaluation of Corporate Sustainability in Context of The Jevons. SocioEconomic Challenges, 4(3), 46-65. https://doi.org/10.21272/sec.4(3).46-65.2020.

6. Clemens, B. (2006). Economic incentives and small firms: Does it pay to be green? Journal of Business Research, 59(4), 492-500. https://doi.org/10.1016/j.jbusres.2005.08.006.

7. Deloitte (2018). The rise of the social enterprise. 2018 Deloitte Global Human Capital Trends. Available at:https://www2.deloitte.com/content/dam/Deloitte/pa/Documents/human-capital/2018/2018HCTrends Rise-of-the-socialenterprise.pdf?fbclid=IwAR3POOk 06xvIkAmfYF8Rye2NXk5ITs8VqeHt20HSo83jJx-MHCXdScsUxg.

8. Dhahri, S., and Omri, A. (2018). Entrepreneurship Contribution to the Three Pillars of Sustainable Development: What Does the Evidence Really Say? MPRA Paper, 84504. 47 p. Available at: https://mpra.ub.uni-muenchen.de/84504/1/MPRA_paper_84504.pdf.

9. El Amri, A., Boutti, R., Rodhain, F. (2020). Sustainable Finance at the time of Institutions: Performativity through the lens of Responsible Management in Morocco. Financial Markets, Institutions and Risks, 4(2), 52-64. https://doi.org/10.21272/fmir.4(2).52-64.2020.

10.European Commission (2021). Eco-innovation Action Plan. Available at: https://ec.europa.eu/environment/ecoap/index_en.htm_en.

11.Fichter, K., and Tiemann, I. (2020). Impacts of promoting sustainable entrepreneurship in generic business plan competitions. Journal of Cleaner Production, 267, 122076, 14 p. https://doi.org/10.1016/j.jclepro.2020.122076.

12.Greco, A., and de Jong, G. (2017). Sustainable entrepreneurship: definitions, themes and research gaps. University of Groningen. Centre for Sustainable Entrepreneurship Working paper series. 36 p. DOI:10.13140/RG.2.2.16751.12968.

13.Husnain, M., Syed, F, Akhtar, W., \& Usman, M. (2020). Effects of Brand Hate on Brand Equity: The Role of Corporate Social Irresponsibility and Similar Competitor Offer. Marketing and Management of Innovations, 3, 75-86. http://doi.org/10.21272/mmi.2020.3-06.

14.Hussain, S.A., Haq, M.A.U., \& Soomro, Y.A. (2020). Factors Influencing Consumers' Green Purchase Behavior: Green Advertising as Moderator. Marketing and Management of Innovations, 4, 144-153. http://doi.org/10.21272/mmi.2020.4-11.

15.Jahanshahi, A.A., Brem, A., and Bhattacharjee, A. (2017). Who Takes More Sustainability-Oriented Entrepreneurial Actions? The Role of Entrepreneurs' Values, Beliefs and Orientations. Sustainability, 9(10), 1636. https://doi.org/10.3390/su9101636.

16.Kaya, H.D. (2020). Business Friendliness, Firm Performance and Owner's Optimism. Financial Markets, Institutions and Risks, 4(3), 13-23. https://doi.org/10.21272/fmir.4(3).13-23.2020.

17.Konys, A. (2019). Towards Sustainable Entrepreneurship Holistic Construct. Sustainability, 11, 6749. https://doi.org/10.3390/su11236749. 
18.Lüdeke-Freund, F. (2020). Sustainable entrepreneurship, innovation, and business models: Integrative framework and propositions for future research. Business Strategy and Environment, 29, 665-681. https://doi.org/10.1002/bse.2396.

19.Moya-Clemente, I., Ribes-Giner, G., and Pantoja-D1'az, O. (2020). Identifying environmental and economic development factors in sustainable entrepreneurship over time by partial least squares (PLS). PLoS ONE, 15(9), e0238462. https://doi.org/10.1371/journal.pone.0238462.

20.Nicholls, A. (2010). The legitimacy of social entrepreneurship: reflexive isomorphism in a preparadigmatic field. Entrepreneurship theory and practice, 34(4), 611-633. https://doi.org/10.1111/j.15406520.2010.00397.x.

21.O'Neil, I., and Ucbasaran, D. (2016). Balancing "what matters to me" with "what matters to them": Exploring the legitimation process of environmental entrepreneurs. Journal of Business Venturing, 31(2), 133-152. https://doi.org/10.1016/j.jbusvent.2015.12.001.

22.Păunescu, C., Drăgan, D., Cantaragiu, R., and Filculescu, A. (2013). Towards a Conceptualization of Social Entrepreneurship in Higher Education. The International Journal of Management Science and Information Technology, 10, 51-69. Available at: https://www.econstor.eu/bitstream/10419/97880/1/786337125.pdf.

23.Rodríguez-García, M., Guijarro-García, M., and Carrilero-Castillo, A. (2019). An Overview of Ecopreneurship, Eco-Innovation, and the Ecological Sector. Sustainability, 11, 2909. https://doi.org/10.3390/su11102909.

24.Sajjad, M., Orangzab, Chani, M.I. (2020). Business Innovations for Unfolding Stratums of Human Development Indicators: A Worldwide Empirical Analysis. Marketing and Management of Innovations, 3 , 11-21. http://doi.org/10.21272/mmi.2020.3-01.

25.Saleem, F., Adeel, A., Ali, R., and Hyder, S. (2018). Intentions to adopt ecopreneurship: moderating role of collectivism and altruism. Entrepreneurship and Sustainability Issues, Entrepreneurship and Sustainability Center, 6(2), 517-537. https://doi.org/10.9770/jesi.2018.6.2(4).

26.Schlange, L.E. (2006). What drives sustainable entrepreneurs. Applied Business and Entrepreneurship Association International Conference: 1-11. Available at: https://www.researchgate.net/publication/326543603_What_Drives_Sustainable_Entrepreneurs.

27.Sharir, M., and Lerner, M. (2006). Gauging the success of social ventures initiated by individual social entrepreneurs. Journal of World Business, 41(1), 6-20. https://doi.org/10.1016/j.jwb.2005.09.004.

28.Shin, C., and Park, J. (2019). How Social Entrepreneurs' Value Orientation Affects the Performance of Social Enterprises in Korea: The Mediating Effect of Social Entrepreneurship. Sustainability, 11, 5341. https://doi.org/10.3390/su11195341.

29.Tarnanidis, T., and Papathanasiou, J. (2015). Sustainable entrepreneurship: What it is? Can we measure it? Proceedings of the 4th International Symposium \& 26th National Conference on Operational Research. Technical University of Crete and the Hellenic Operational Research Society (HELORS), 4-6 June 2015, Chania-Greece. Available at: https://www2.deloitte.com/content/dam/Deloitte/pa/Documents/humancapital/2018/2018-HCTrends_Rise-of-the-socialenterprise.pdf?fbclid=IwAR3POOk 06xvIkAmfYF8Rye2NXk5ITs8VqeHt20HSo83jJx-MHCXdScsUxg.

30.Tsalikis, J., Seaton, B. (2020). Corporate Social Responsibility: A Cross-National Study of the Treatment of Consumers and Employees. Business Ethics and Leadership, 4(2), 6-15. https://doi.org/10.21272/bel.4(2).6-15.2020.

31.Ubreziova, I., Diacikova, A., Sokil, O., \& Apostol, S. (2020). Innovation Ecosystems for the Moldovan Small and Medium-Sized Enterprises. Marketing and Management of Innovations, 2, 298-312. http://doi.org/10.21272/mmi.2020.2-22.

32.Uhlaner, L.M., Berent, M.M., Jeurissen, R.J., and de Wit, G. (2010). Family ownership, innovation and other context variables as determinants of sustainable entrepreneurship in SMEs: An empirical research study. EIM Research Reports, 201006, 1-29. Available at: https://ideas.repec.org/p/eim/papers/h201006.html.

33.Umadia, K.Sr., Kasztelnik, K. (2020). The Financial Innovative Business Strategies of Small to Medium Scale Enterprises in Developing Country and Influence for the Global Economy Performance. SocioEconomic Challenges, 4(3), 20-32. https://doi.org/10.21272/sec.4(3).20-32.2020.

34.Urbaniec, M. (2018). Sustainable Entrepreneurship: Innovation-Related Activities in European Enterprises. Polish Journal of Environmental Studies, 27(4), 1773-1779. https://doi.org/10.15244/pjoes/78155. 